\title{
Assessment of soil and ground chemical and radiation pollution on the gold-silver deposit "Klyon" territory (Chukotka Autonomous Region, Russia)
}

\author{
Alexey Vinogradov ${ }^{1, *}$, Fedor Bryukhan ${ }^{2}$ and Alexey Kuchmin $^{3}$ \\ ${ }^{1}$ Saint Petersburg State Forest Technical University, Institutskiy per., 5, Saint-Petersburg, 194021, \\ Russia \\ ${ }^{2}$ Moscow State University of Civil Engineering, Yaroslavskoe sh. 26, 129337 Moscow, Russia \\ ${ }^{3}$ NPO Gidrotekhproekt, Oktyabr'skaya str. 55A, 175400 Valday City, Novgorod Region, Russia
}

\begin{abstract}
Study of Arctic soils and grounds ecological state is relevant on the one hand due to their industrial development, on the other hand due to the need to preserve natural landscapes considering their high sensitivity to technogenic impacts. This study is aimed at assessing soil and ground chemical and radiation pollution on the territory of the gold-silver deposit "Klyon" located in Chukotka permafrost zone. The level of metal content in soil and ground samples was found to differ from the world soil clarke insignificantly. Field measurements of gamma radiation flux on the deposit sites under development have shown external equivalent dose rate of the gamma radiation to be at the natural gamma background level. Laboratory tests of soil and ground samples have shown their radioactivity level to meet radiation safety standards for construction materials. Studying changes of soil and ground chemical and radiation pollution over time as part of local environmental monitoring is noted to be expedient.
\end{abstract}

\section{Introduction}

Considerable part of mining enterprises is designed to extract and process non-ferrous and rare metals. These metals, in turn, are toxic pollutants and pose a serious danger to the environment [1]. Enterprise infrastructure development, mineral raw materials mining and processing are in most cases accompanied by significant deterioration of natural landscape due to exposure to various technogenic factors. To develop environmental safety tools for protection against mining enterprises negative impacts, complex studies of geoecological state of their location territories are provided [1,2].

Most of the Russian non-ferrous and rare metal deposits are in hard-to-reach and sparsely populated areas, particularly, in the Arctic zones [3]. Before enterprise infrastructural development and operation the natural landscapes had been intact and, in many cases, had represented valuable natural sites. Therefore, infrastructural development and operation of

\footnotetext{
* Corresponding author: pniiis-gip@mail.ru
} 
new deposits requires environmental protection activities, which, in turn, provide for a detailed study of initial ecological state of mining enterprises location territory.

Mining industry is known to give rise to serious environmental problems, which are most acute in permafrost conditions, where natural landscapes are most sensitive to technogenic impacts and recover slowly [1, 2]. Intensive advancement of mining industry, significant technogenic burden to the environment caused by mining enterprises and the need to address relevant environmental challenges determine the relevance of a comprehensive assessment of geoecological state of the deposit territory to be developed.

One of the promising gold-silver deposits, in terms of development, is the "Klyon", where construction of a mining enterprise currently proceeds to completion. The deposit is located in Chukotka Autonomous Region (Figure 1). This paper is aimed at assessing soil and ground chemical and radiation pollution on the territory of this deposit. The paper is based on the results of engineering and environmental surveys conducted by Scientific \& Industrial Association Gidrotekhproekt for environmental feasibility study under enterprise infrastructure development project.

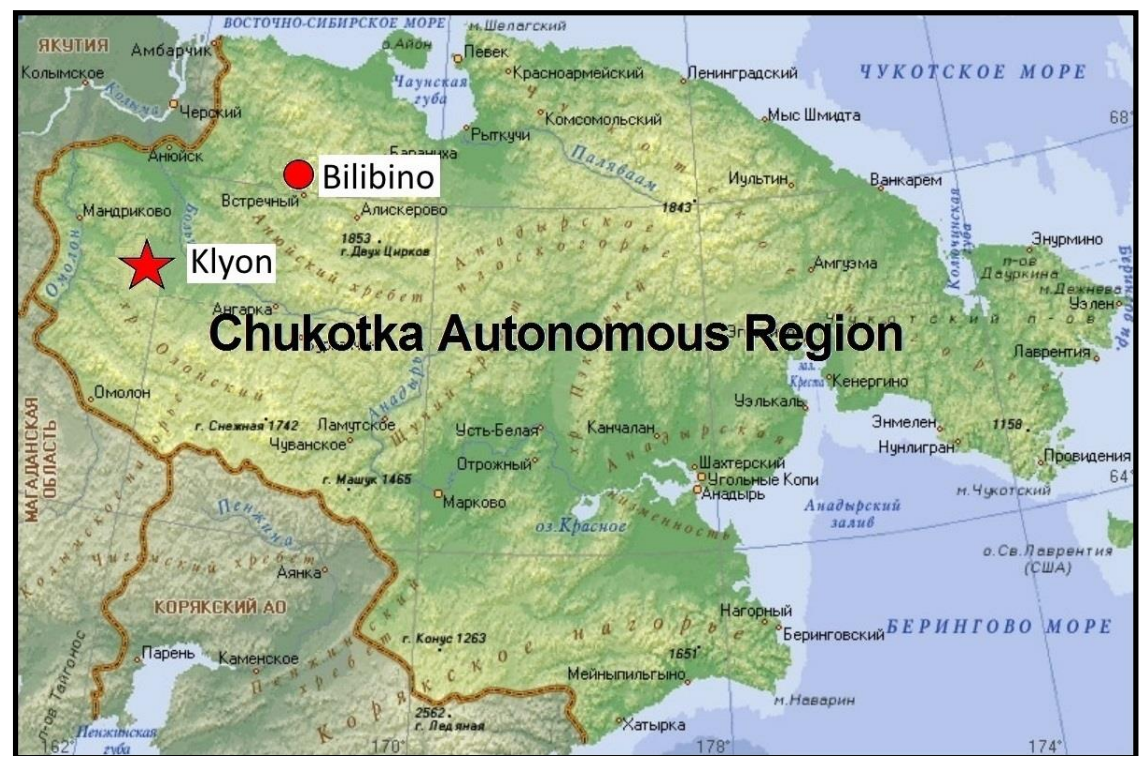

Fig. 1. Location of the Klyon deposit on the map of Chukotka.

\section{Brief description of natural conditions of the studed territory}

The deposit is located about $250 \mathrm{~km}$ away from the town of Bilibino - the nearest settlement. Area of the deposit localized in the interfluve of small rivers Klyon and Alisa in the Krichalskaya River basin is about $1.5 \mathrm{~km}^{2}$. An overview photo of the deposit territory taken from helicopter is shown in Figure 2. Approved gold reserves of the deposit are $17.6 \mathrm{t}$, those of silver are $43.8 \mathrm{t}$. Planned deposit life is 10 years. Deposit industrial operation is scheduled to start in 2018. At present, enterprise infrastructure development proceeds to completion.

The deposit territory is in the permafrost zone in the south-eastern part of the Kuryinskiy ridge on the Yukagir plateau and belongs to the forest-tundra with valley forests. Seasonal thaw depth varies from 0.5 to $1.5 \mathrm{~m}$. 


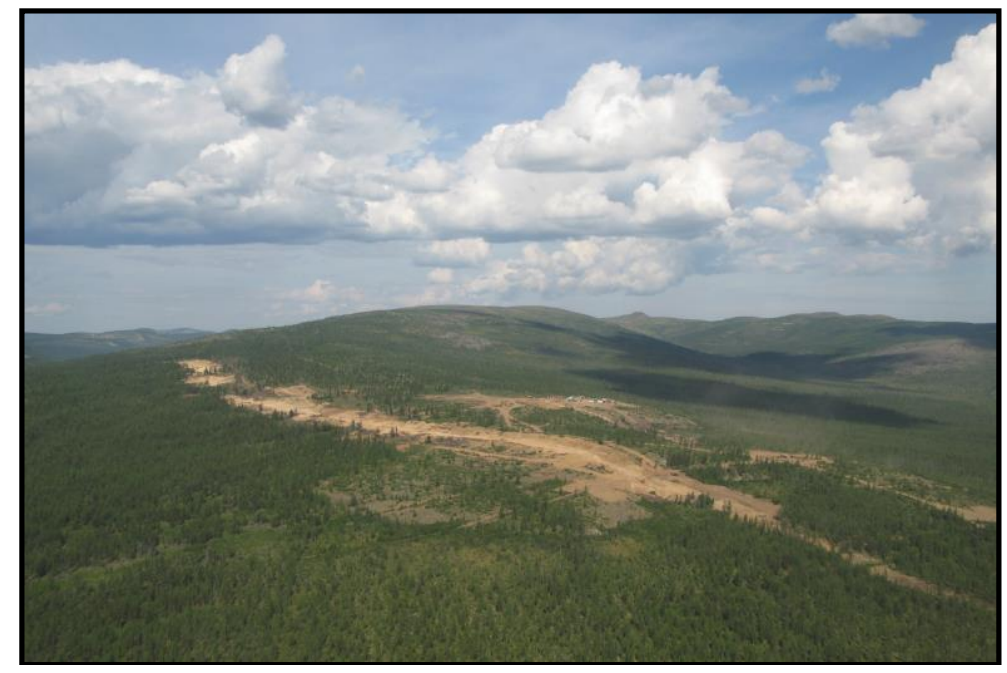

Fig. 2. The deposit territory photo taken from helicopter.

The territory is characterized by severe winters and cool summers. Average monthly temperatures in January and July are $-35.6^{\circ} \mathrm{C}$, and $+12.8^{\circ} \mathrm{C}$, respectively. Northern and northwestern as well as southern and south-eastern winds prevail throughout the year. Stable snow cover is usually set in early October and lasts until mid-May.

The Klyon and Alisa Rivers flow from north to south in the west and east of the deposit. Rivers hydrological regime on this territory is determined by severe climatic conditions, ruggedness of the relief and widespread permafrost. The Klyon and Alisa Rivers are characterized by significant changes in flow within the year, which consist in high spring flood, frequent summer high waters and winter low water. River inflow is mixed: snow (47 $\%$ ), rain (42\%), underground sources (11\%). Spring-summer flow share is $90-95 \%$ of the annual volume.

Mountain forests and woodlands are spread up to 250-280 m elevations. Above these elevations there are thickets of cedar shrubs. Hill tops are classified as a tundra-shrub zone, within the boundaries of which the shrubs are replaced by mosses and lichens on the stone fields. The animal life is typical of forest taiga zone. It is inhabited by lynx, bear, hare, rodents, fox, capercaillie, hazel grouse, partridge, and flying ducks. Gophers and mice are most commonly encountered among the small rodents. The species composition of ichthyofauna is represented by grayling, peled, pike, burbot, lenok, whitefish, and coregonus nasus whitefish.

\section{Studying of soil and ground pollution}

For environmental feasibility study under the "Klyon" enterprise infrastructure development project, the experts of Scientific \& Industrial Association Gidrotekhproekt carried out engineering and environmental survey. The survey included study of soil and ground chemical and radiation pollution at the deposit, which provided for:

- collection, processing and analysis of published and library materials on soil and ground pollution;

- preliminary site investigation and selection of sampling points;

- mixed soil and ground sampling;

- samples laboratory analyses;

- laboratory analyses results processing. 
The survey was carried out in accordance with current engineering survey regulatory and technical documents $[4,5]$. During field works, 26 mixed soil and ground samples were taken. Additionally, equivalent gamma radiation dose rate was measured as part of the field works. All the samples were subjected to multi-element chemical analysis, 6 of them were additionally examined for radionuclide composition.

\section{Results and discussion}

\subsection{Chemical pollution}

Since the threshold limit values (TLV) of many chemical elements in soil and ground were not developed, level of their chemical pollution was estimated by comparing the concentrations of various elements in the samples with corresponding world soil clarkes according to Bowen [6]. Concentration coefficients $K_{c}$ - ratios of element concentrations in the samples to the corresponding clarkes - were determined. Averaged data for all the samples from the deposit are given in Table 1.

Table 1. Average values of soil and ground pollution characteristics.

\begin{tabular}{|c|c|c|c|c|c|}
\hline \multirow{2}{*}{ Elements } & \multirow{2}{*}{$\begin{array}{c}\text { Soil clarkes, } \\
\mathrm{mg} / \mathrm{kg}\end{array}$} & \multicolumn{2}{|c|}{ Technogenic sites } & \multicolumn{2}{c|}{ Background sites } \\
\cline { 3 - 6 } & $\begin{array}{c}\text { Average } \\
\text { value, } \mathrm{mg} / \mathrm{kg}\end{array}$ & $K_{c}$ & $\begin{array}{c}\text { Average } \\
\text { value, } \mathrm{mg} / \mathrm{kg}\end{array}$ & $K_{c}$ \\
\hline $\mathrm{Fe}$ & 40000 & 40625 & 1 & 40000 & 1 \\
\hline $\mathrm{Mn}$ & 1000 & 412.5 & 0.4 & 450 & 0.5 \\
\hline $\mathrm{Ni}$ & 50 & 32.5 & 0.7 & 35 & 0.7 \\
\hline $\mathrm{Co}$ & 8 & 18.4 & 2.3 & 17 & 2.1 \\
\hline $\mathrm{Ti}$ & 5000 & 2875 & 0.6 & 3100 & 0.6 \\
\hline $\mathrm{V}$ & 90 & 90 & 1 & 80 & 0.9 \\
\hline $\mathrm{Cr}$ & 70 & 80 & 1.1 & 78 & 1.1 \\
\hline $\mathrm{W}$ & - & - & - & 5 & - \\
\hline $\mathrm{Mo}$ & - & 3.9 & - & 4 & - \\
\hline $\mathrm{Zr}$ & - & 140.6 & - & 175 & - \\
\hline $\mathrm{Nb}$ & - & - & - & 10 & - \\
\hline $\mathrm{Cu}$ & 30 & 44.4 & 1.5 & 38 & 1.3 \\
\hline $\mathrm{Pb}$ & 12 & 22.2 & 1.8 & 29 & 2.4 \\
\hline $\mathrm{Sb}$ & - & 26.7 & - & - & - \\
\hline $\mathrm{Bi}$ & - & 1.5 & - & 1 & - \\
\hline $\mathrm{Cd}$ & - & - & - & 10 & - \\
\hline $\mathrm{Ag}$ & - & 0.2 & - & 0.1 & - \\
\hline $\mathrm{Zn}$ & 90 & 123.8 & 1.4 & 153 & 1.7 \\
\hline $\mathrm{Sn}$ & - & 4.2 & - & 4.7 & - \\
\hline $\mathrm{Be}$ & - & 1.8 & - & 2 & - \\
\hline $\mathrm{Sc}$ & - & 5 & - & 5 & - \\
\hline $\mathrm{Ga}$ & - & 20.9 & - & 20 & - \\
\hline $\mathrm{P}$ & - & 656.3 & - & 660 & - \\
\hline $\mathrm{Sr}$ & 250 & 337.5 & 1.4 & 370 & 1.5 \\
\hline $\mathrm{B}$ & - & 325 & - & 240 & - \\
\hline & & & & & \\
\hline $\mathrm{H}$ & - & & - & & - \\
\hline
\end{tabular}

When assessing soil and ground pollution, two categories of sampling sites were distinguished: those exposed to technogenic impact during geological survey (technogenic sites) and undisturbed (background) sites. To identify pollution levels, the chemical elements were divided into three groups:

- Group $1\left(0.7 \leq K_{c} \leq 1.5\right)$ : Fe, $\mathrm{Ni}, \mathrm{V}, \mathrm{Cr}, \mathrm{Cu}, \mathrm{Sr}$ - concentrations close to clarkes; 
- Group $2\left(K_{c}>1.5\right)$ : $\mathrm{Co}, \mathrm{Pb}, \mathrm{Zn}$ - increased concentrations relative to clarkes;

- Group $3\left(K_{c}<0.7\right)$ : Mn, Ti - decreased concentrations relative to clarkes.

The analysis of Table 1 shows that metal content in soil and ground differs slightly from the world clarkes. Chemicals migrate in soil and ground because of two counteracting processes - biogenic accumulation and leaching, which depends mainly on acid-base conditions $(\mathrm{pH})$ and oxidation-reduction processes. Permafrost has also a significant impact on substances migration conditions. On the one hand, it sharply weakens all biogeochemical and biological processes. On the other hand, salts are frozen out under permafrost processes impact $[2,7]$.

Conditions of substances migration and accumulation in soil and ground within the deposit are largely determined by their cationic and anionic composition. Results of statistical processing of all significant parameters of soil and ground acid-base composition are shown in Table 2. According to Table 2, the largest concentrations of mobile ion forms are observed on the technogenic site of the deposit. The soil and ground layer is characterized by an acidic or slightly acidic reaction, less often by neutral reaction at $\mathrm{pH}$ values ranging from 5.1 to 7.3. In general, weak acidity on the undisturbed sites can be caused by organic acids that enter the soil with vegetation debris or root secretions. Higher $\mathrm{pH}$ values are noted at the technogenic sites.

Table 2. Cationic and anionic composition of soil and ground samples water extract.

\begin{tabular}{|c|c|c|c|c|c|c|c|c|}
\hline \multirow[b]{2}{*}{ Parameters } & \multirow{2}{*}{$\begin{array}{c}\text { Specific } \\
\text { conductivity, } \\
\mu \mathrm{S} / \mathrm{cm}\end{array}$} & \multirow[t]{2}{*}{$\mathrm{pH}$} & \multicolumn{4}{|c|}{ Anions, $\mathrm{mg} / \mathrm{kg}$} & \multicolumn{2}{|c|}{ Cations, $\mathrm{mg} / \mathrm{kg}$} \\
\hline & & & $\mathrm{CO}_{3}{ }^{2-}$ & $\mathrm{HCO}_{3}^{-}$ & $\mathrm{SO}_{4}{ }^{2-}$ & $\mathrm{Cl}^{-}$ & $\mathrm{Ca}^{2+}$ & $\mathrm{Mg}^{2+}$ \\
\hline \multicolumn{9}{|c|}{ Technogenic site soils and grounds } \\
\hline Minimum & 27.6 & 5.1 & $<10$ & 36.6 & 175.0 & 17.7 & 12.0 & 6.1 \\
\hline Maximum & 215.6 & 7.3 & $<10$ & 207.0 & 263.0 & 28.4 & 146.0 & 31.7 \\
\hline Average & 90.7 & 6.4 & $<10$ & 124.3 & 209.0 & 23.1 & 65.8 & 15.5 \\
\hline \multicolumn{9}{|c|}{ Background site soils and grounds } \\
\hline Minimum & 34.5 & 5.4 & $<10$ & 54.9 & 148.0 & $<10$ & 18.0 & 6.1 \\
\hline Maximum & 112.1 & 6.8 & $<10$ & 137.0 & 148.0 & $<10$ & 58.0 & 19.5 \\
\hline Average & 58.2 & 6.0 & $<10$ & 93.7 & 148.0 & $<10$ & 35.4 & 11.5 \\
\hline
\end{tabular}

Soil solution specific conductivity is quite changeable and varies from 27.6 to 216.6 $\mu \mathrm{S} / \mathrm{cm}$. Against the background of low specific conductivity values, conductivity of over 200 $\mu \mathrm{S} / \mathrm{cm}$ corresponding to high ion concentrations in samples taken at the technogenic sites is noted. As it follows from Table 2, soils and grounds are characterized by near-complete absence of carbonate ions $(<10 \mathrm{mg} / \mathrm{kg})$. The highest content of sulphates is noted on the technogenic territory, where their values range from 175 to $263 \mathrm{mg} / \mathrm{kg}$. Total distribution of chlorides at different sites is quite changeable, its values vary from 17.7 to $28.4 \mathrm{mg} / \mathrm{kg}$. Solution cationic composition is quite changeable, calcium is a predominant element for all landscapes. Single highest concentrations of calcium and magnesium are recorded on the technogenic sites. Practically all anomalies in the cationic and anionic composition of samples water extract across the studied territory are due to technogenic impact.

Earthworks during construction provide for removal of a 20 -cm layer of soil, its stacking and subsequent use during territory reclamation.

\subsection{Radiation pollution}

Possible sources of radiation impact on mining enterprise personnel may theoretically be an increased gamma-background of the territory as well as soil and ground radioactivity. Therefore, special attention during engineering survey was paid to the study of gamma background at residential premises and industrial zones construction sites, as well as to 
radioactivity of the soil and ground samples from these sites. The total area of these sites (shift camp and processing facility construction sites) was 1.84 ha. To measure equivalent dose rate of the gamma radiation, a route gamma survey was performed using the survey gamma radiometer SRP-97. According to the measurements, the external equivalent dose rate of the gamma radiation on the studied sites was found to vary from 0.09 to $0.24 \mu \mathrm{Sv} / \mathrm{h}$ and to be at the natural gamma background level.

As we mentioned above, 6 mixed soil and ground samples were taken during field survey to subsequently analyze them for radioactivity. The laboratory study provided for determination of specific activity of technogenic $\mathrm{Cs}^{137}$ and the following natural radionuclides: $\mathrm{K}^{40}, \mathrm{Ra}^{226}, \mathrm{Th}^{232}$. The results of this study are shown in Table 3.

Table 3. The results of $\mathrm{Cs}^{137}, \mathrm{~K}^{40}, \mathrm{Ra}^{226}$ and $\mathrm{Th}^{232}$ specific activity laboratory study on mixed soil and ground samples, $\mathrm{Bq} / \mathrm{kg}$.

\begin{tabular}{|l|c|c|c|c|c|c|}
\hline \multirow{2}{*}{ Parameters } & \multicolumn{7}{|c|}{ Sample numbers } \\
\cline { 2 - 7 } & 1 & 2 & 3 & 4 & 5 & 6 \\
\hline $\mathrm{Cs}^{137}$ & $<9$ & $<7$ & $<8$ & $<8$ & $<8$ & $<6$ \\
\hline $\mathrm{K}^{40}$ & 440 & 450 & 540 & 460 & 350 & 350 \\
\hline $\mathrm{Ra}^{226}$ & 22 & 24 & 22 & 20 & 19 & 17 \\
\hline $\mathrm{Th}^{232}$ & 43 & 33 & 33 & 34 & 34 & 27 \\
\hline $\begin{array}{l}\text { Specific effective activity } \\
\text { of natural radionuclides }\end{array}$ & 116 & 107 & 113 & 107 & 94 & 83 \\
\hline
\end{tabular}

A threshold value of $370 \mathrm{~Bq} / \mathrm{kg}$ is established for natural radionuclides specific effective activity in [8] as a criterion for making decision on the use of building materials. Soil and ground may be used for any types of construction activities at the values of these parameters not exceeding the established threshold value. Thus, radioactivity level of the soil and ground samples meets the established radiation safety standards for building materials.

To identify trends in soil and ground pollution during deposit operation, local environmental monitoring provides for studies of change in the level of their chemical and radiation pollution over time.

\section{Conclusions}

- Soil and ground were studied for chemical and radiation pollution as part of engineering and environmental survey on the territory of the gold-silver deposit "Klyon".

- According to the results of chemical analysis of 24 mixed soil and ground samples, the level of metal content in the samples was found to differ from the world soil clarke insignificantly. Increased concentrations of mobile ion forms were found observable at the deposit technogenic site. In general, the soil and ground layer on the deposit territory is characterized by acidic or weakly acidic reaction. Practically all anomalies in the cationic and anionic composition of samples water extract are due to technogenic impact.

- Field measurements of gamma background at the shift camp and processing facility construction sites have shown external equivalent dose rate of the gamma radiation to vary from 0.09 to $0.24 \mu \mathrm{Sv} / \mathrm{h}$ and to be at the natural gamma background level.

- Laboratory tests of 6 soil and ground samples have shown their radioactivity level to meet radiation safety standards for construction materials.

- Studying changes of soil and ground chemical and radiation pollution over time as part of local environmental monitoring is noted to be expedient.

\section{References}

1. Guidebook for evaluating mining project EIAs (Eugene, OR, ELAW, 2010) 
2. F.F. Bryukhan, V.V. Lebedev, Kriosfera Zemli, 16 (2012)

3. E. Safirova, The Mineral Industry of Russia (USGS Minerals Yearbook, 2014)

4. Russian Standard SP11-102-97

5. Russian Standard SP 47.13330.2012

6. H.J.M Bowen, Environmental chemistry of the elements (NY, Academic Press, 1979)

7. W.F. Vincent, M. Lemay, Mag. Arctic Science 3, 2 (2017)

8. Russian Standard GOST 30108-94 